\section{Exxon cleans up, clears off}

\section{San Francisco}

AFIER "one of the most massive mobilizations of manpower and equipment in peacetime history", Exxon last week officially closed oil-spill clean-up operations in Alaska for the winter. But it leaves behind hundreds of miles of contaminated shoreline, and strained relations with government officials and private parties.

Many officials involved in the clean-up charged Exxon with shying away from an obligation to continue fighting the spill, and Alaska's Governor Steve Cowper announced that the state would continue the work that Exxon has now abandoned, and would submit at least part of the expected $\$ 21$ million bill to Exxon.

The 11 million barrels of crude oil that spilled into Prince William Sound last March, when the Exxon tanker Valdez struck a reef, has since drifted southwest into the Gulf of Alaska, tarnishing an estimated 1,100 miles of shoreline. The US Fish and Wildlife Service (USFWS) reported last week that 34,434 birds and 994 sea otters had died as a result of the catastrophe, and officials estimated the toll could reach 10 times these numbers.

Exxon has already spent $\$ 1,000$ million on the clean-up, including approximately $\$ 90$ million to settle claims against itself. The company still faces another 140 lawsuits, including one from the state of Alaska, which is seeking unspecified punitive and compensatory damages for a series of alleged violations of state, common and general maritime laws.

Years of comprehensive scientific studies will be needed to assess how marine life and natural resources have been affected. One early result points to a dramatic decline in bald eagle productivity. In the oiled area, 16 eaglets were born for every 100 nests, compared with 49 eaglets in the Copper River Delta just east of the sound. And two-thirds of the occupied nests in the contamination zone failed to produce any young at all, compared to 29 per cent in the non-oiled area.

To counteract public outcry against its decision, Exxon has stressed that it is not going away. A winter crew of 300 people will be retained, and the company has promised to return in the spring to see what, if anything, remains to be done.

Exxon objects to the accusations that it has not pulled its weight. Otto Harrison, general manager of Valdez operations for Exxon USA, says his firm has met its objectives to protect fish hatcheries, skim oil off the water, and treat the affected shoreline by mid-September. The company has 'treated' - the formal term for completing basic clean-up on a stretch of shoreline and receiving permission from

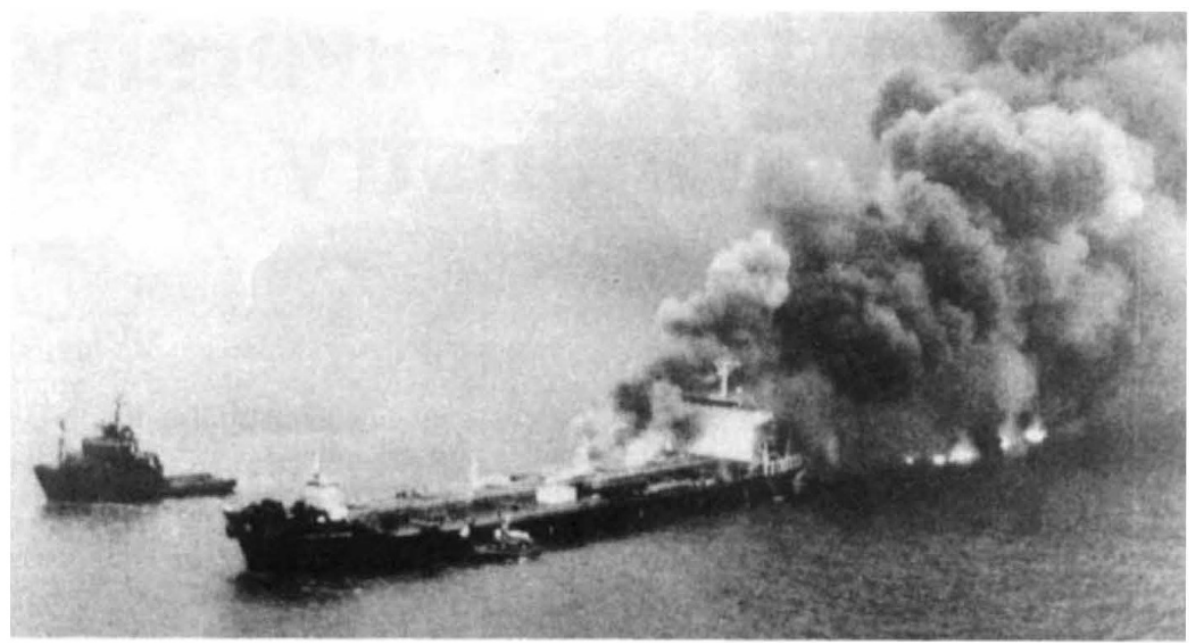

Another environmentally sensitive area was threatened by an oil spill at the weekend - this time the Humber estuary and Spurn peninsula on England's north-east coast. Both are 'Sites of Special Scientific Interest', with large bird populations. The Phillips Oklahoma (above) and Fiona collided and both caught fire. (Press Association.)

the US Coast Guard to move on - more than 1,100 miles of shoreline. The treated shoreline is, said Harrison, "environmentally stable", meaning that the beaches are in a condition that will not harm marine or animal life.

But state officials are not satisfied. "The term 'environmentally stable' was created by Exxon, really out of the need to say that they had accomplished something", said Joe Ferguson of the Alaska Department of Environmental Conservation. "It is not a term that we use or agree with."'

Removing all the oil is impossible, because some has soaked several feet into the shoreline soil. But state officials charge that so far Exxon has provided mainly cursory treatment - such as blasting oil off the tops of rocks with hot water - and that a much more comprehensive effort will be needed next spring.

HUMAN GENOME

\title{
Sequencing bargain in India?
}

\section{New Delhi}

PRIME Minister Rajiv Gandhi is being urged to launch India's own project to map the human genome, on the grounds that other countries which have already begun the task may not share their results with the rest of the world, and that in any case India might be able to do the job more cheaply.

Genome mapping is not a high priority at the Indian Department of Biotechnology (DBT), whose annual budget is $\$ 30$ million. But Pushpa Bhargava, director of the Centre for Cellular and Molecular Biology in Hyderbad and a member of DBT's scientific advisory committee, claims that India has "all the capabilities" to do the work, and at a fraction of what the United States plans to spend.

Because most of the money spent on the project would go towards salaries, India could map the entire human genome for less than \$200 million spread over 15 years,
USFWS is unhappy with efforts to gauge the spill's effect on fall migration of a variety of bird species, including petrels and shearwaters. The USFWS has asked Exxon to maintain at least six boats in the Kodiak Island area to monitor the migration, but spokesman Bruce Batten said that Exxon has apparently decided "to pull out all of the boats. And so we're left with a job that we're still trying to get done with our own resources, and to some extent volunteers."

A kinder judgement came from the Coast Guard, which co-ordinated the clean-up. Exxon has "done as much as could be done in a short period under very difficult conditions", said Vice-Admiral Clyde Robbins, the highest-ranking federal official in Valdez, and added that the oil posed "no great threat" over the winter.

Robert Buderi according to Bhargava. He also argues that India could put itself in a good bargaining position with other countries who want the results. But a more compelling reason, Bhargava suggested to Gandhi, is that India might not benefit from human genome work going on elsewhere.

Bhargava's proposal has few supporters, however, and many disagree with his cost estimate. According to S. Ramachandran, secretary to DBT, the project would require not just manpower, of which India has a plentiful supply, but also equipment, reagents and enzymes, which would have to be imported. And G. Padmanbhan of the Indian Institute of Science, one of six laboratories in the country with the facilities to sequence DNA, "would rather sequence the DNA of a pathogenic organism that causes disease in Indians than that of a human being". 